\title{
Factors That Determine Capital Structure in Building Material and Construction Listed Firms: Egypt Case
}

\author{
Amr Youssef $^{1} \&$ Ayah El-ghonamie ${ }^{1}$ \\ ${ }^{1}$ Department of Finance and Accounting, College of Management and Technology, Arab Academy for Science, \\ Technology, and Maritime Transport, Egypt
}

Correspondence: Dr. Amr Youssef, Associate Professor, Department of Finance and Accounting, College of Management and Technology, Arab Academy for Science, Technology, and Maritime Transport, Egypt. Tel: 20-122-311-6470

Received: July 29, 2015

Accepted: August 17, 2015

Online Published: August 21, 2015

doi:10.5430/ijfr.v6n4p46

URL: http://dx.doi.org/10.5430/ijfr.v6n4p46

\begin{abstract}
The main aim of this study is to investigate the factors that affect the capital structure of the Egyptian firms for building materials and construction sector and to analyze capital structures and whether optimal capital structure exists or not. A number of relevant theories of capital structure are reviewed, namely; the trade-off, pecking order and agency theories, in order to initiate some testable propositions concerning these factors that determine the capital structure of the building materials and construction Egyptian firms. This exploration is performed using panel data procedures for a sample of 18 firms listed on the Egyptian Stock Exchange during the period from 2003 thru 2012. The results recommended that profitability is negatively related to debt ratios (LTDR, TDR); whereas firm tangibility is positively linked to the debt ratios. Size, Non-debt taxes shields, liquidity and growth opportunities do not appear to be significantly related to the debt ratios. The findings of this study are consistent with the predictions of the trade-off theory, pecking order theory, and agency theory which show that capital structure models derived from these theories provide some help in understanding the financing behavior of Egyptian firms for building materials and construction sector. This study provided some groundwork to explore the factors that determine the capital structure of Egyptian firms for building materials and construction sector upon which a more detailed study could be based. Furthermore, findings should assist corporate managers to optimize their capital structure decisions. To the best of the authors' knowledge, this study considers from the pioneering studies that explore the factors that determine the capital structure of the Egyptian building materials and construction firms by using the most recent available data. Moreover, this study to a certain extent goes to confirm the similarity of factors that affect the capital structure decisions in both developing and developed countries.
\end{abstract}

Keywords: capital structure, agency theory, picking order theory, trade-off theory, Egypt

\section{Introduction}

Capital structure refers to the combination of a firm's liabilities and owners' equity, which means that capital structure of a firm, is a specific mix of all the claims on the firm (debt and equity) that is used to fund its operations and expansions. Capital structure decisions is one of the three financing decisions, the financial managers must make - investment, financing, and dividends. Therefore, decisions concerning capital structure are essential for every firm. It is the job of the financial management to reach the optimal capital structure, which is the one that maximizes the firm value, while minimizing the firm's cost of capital. However, the maximization of firm value is a very hard job because it involves the selection of debt and equity combination in a balanced proportion taking into consideration different costs and benefits related to different combinations. A bad decision in this selection process may lead the firm to financial distress and eventually to bankruptcy. As well as any action the financial management will take that impact the firm's performance, and affect how the investors will estimate and perceive the firm.

This study is going through different theories of capital structure that are relevant to the studied phenomenon, as no consensus has been reached so far even within the context of developed economies. This maybe because of the fact that these theories differ in their emphasis, for example, the trade-off theory emphasizes taxes, the pecking order theory emphasizes differences in information, and the agency costs theory emphasizes free cash flow. 
This study also identifies some variables, namely, profitability, size, non-debt tax shields, tangibility (asset structure), growth opportunities, earnings volatility, and liquidity, that were highlighted their effect -from previous literatureon the choice of optimal capital structure. This study utilizes panel data procedures as the sample contained data across firms and overtime. The sample was consisted of the building and material Egyptian firms listed on the Egyptian Stock Exchange Starting from year 2003 till year 2012. The specification test of Hausman (1978) was employed in order to know if a fixed or random effect model is the best to explain our estimation.

The results reveal a significant negative relationship between debt level and firm's profitability and firm's size. Also a positive and significant relationship has been confirmed between debt level and firm's tangibility, thus can be concluded that they play a major role in the determination of the financial leverage in Egyptian building material and construction firms while other variables i.e. growth opportunity, non-debt tax shields and liquidity have a weak role.

\section{Capital Structure Theories Review}

The modern theory of capital structure was first discussed by Modigliani and Miller (1958), they provided evidence that the choice between debt and equity financing has no significant effects on the firm's value, therefore, management of a firm should not be worry about the proportion of debt and equity because in case of perfect capital markets any combination of debt and equity is very similar to another one.

However, Modigliani and Miller's debt irrelevance theorem is based on restrictive assumptions which do not exist in reality, when these assumptions are relaxed then choice of capital structure becomes an important determinant factor. For example, considering taxes in their analysis, Modigliani and Miller (1963) stated that firms should use as much debt as possible to make use of the advantage of tax-deductible interest payments, however; they ignored the increased riskiness level of the firm which makes it less attractive.

DeAngelo and Masulis (1980) proposed that companies have different alternatives other than the interest on debt to support income such as depreciation, investment tax credits, and tax loss carry forwards amongst others. Tax shields on interest payments encourage firms to take on more debt, but also increases the probability that earnings in some years may not be sufficient to offset all tax deductions. Therefore, it was noticed that firms with large non-debt tax shields relative to their expected cash flow take less debt in their capital structure.

This view suggests that non-debt tax shields are the substitute of the tax shields on debt finance, and therefore, the relationship between non-debt tax shields and leverage is proposed to be negative.

Although the benefit of tax shields may encourage the firms to employ more debt than other external sources available to them, this mode of finance is not free of costs. Two possible costs, namely, the bankruptcy and agency costs are associated with this debt finance. The use of debt in the capital structure of a firm also might lead to agency costs. As this costs generated as a result of the conflict of relationships between managers and shareholders, and those between debt holders and shareholders (Jensen and Meckling, 1976). However, according to Myers (2001), conflicts between debt holders and shareholders only arise when there is a default risk. If debt is free of default risk, debt holders have no interest in the income and the value or risk of the firm.

The trade-off theory states that firms borrow up to the point where the tax savings from an extra dollar in debt are exactly equal to the costs that come from the increased level of riskiness of the financial distress. Under the trade-off theory framework, it is suggested that firm is setting a target debt to equity level and gradually is trying to reach it which indicates that a form of capital structure optimal level exists that works on maximizing the firm value. The trade-off theory has strong practical appeal as it rationalizes debt levels. This is well noted as companies with relatively safe tangible assets tend to borrow more than companies with risky intangible assets (Karadeniz et al., 2009).

An alternative to trade-off theory is the pecking order theory of Myers and Majluf (1984) and Myers (1984). The pecking order theory is based on two prominent assumptions. First, the managers are better informed about their own firm's prospects than are outside investors. Second, managers act in the best interests of existing shareholders. More specifically, pecking order theory predicts that firms prefer to use internal financing when available and choose debt over equity when external financing is required (Ross, 1977).

Another dependent theory to the capital structure is the agency cost theory, which was provided by Jensen and Meckling (1976), pointed that conflicts of interest between managers and shareholders over payout policies are essentially hard when a firm generate free cash flow. The problem is how to encourage the managers to distribute the free cash among the shareholders instead of reinvesting it at below the cost of capital or wasting it on organizational inefficiencies. 
Several studies have examined the empirical validity of the theories of capital structure, but no universal well accepted theory within the context of developed economies. Since, the orientation of each theory, whether pecking order, trade-off or agency theories, is different as mentioned earlier. Thus, there is no universal theory of debt-equity choice and no reason to expect one (Myers, 2001). However, there are several useful conditional theories that can provide support in understanding the financing behavior of firms.

\section{Determinants of Capital Structure}

This section will illustrate the attributes that are suggested by different conditional theories of capital structure as explained earlier, which may affect the firm's capital structure decisions. These attributes are denoted as profitability, size, non-debt tax shields, tangibility (asset structure), growth opportunities, earnings volatility, and liquidity. The attributes and their relationship to the optimal capital structure choice are discussed below.

\subsection{Profitability}

The trade-off and agency cost theories indicate a positive relationship between profitability and debt ratio as high profitability level can lead to a high level of borrowing capacity and give a motivation to firms to use the benefit of tax shields on interest payments (Karadeniz et al., 2009). While the pecking order theory suggests a negative relationship between profitability and debt ratio (Myers, 1984; Myers and Majluf, 1984; Titman \& Weasels, 1988; Qian and Wirjanto, 2007). Generally, most of the empirical studies results support the pecking order theory (Myers and Majluf, 1984; Titman \& Weasels, 1988; Zou and Xiao, 2006; Serrasqueiro and Rogao, 2009). Finally, Fattouh $e t$ al. (2005) could not prove that profitability is an influential factor on the capital structure decision.

\subsection{Size}

The trade-off theory and the agency cost theory suggest a positive relationship between the firm's size and its debt ratio based on the assumption of that large firms are expected to have a relatively higher debt capacity and have the ability to borrow more since these firms are better diversified and less prone to financial distress and bankruptcy costs, and lower bankruptcy costs give large firms the opportunity to use better the debt financing (Padron et al., 2005; Sheikh and Wang, 2011). Moreover, large firms have a bigger debt capacity because they can access easily to credit markets and can borrow under better conditions comparing with the smaller firms (Sayılgan et al., 2006).

On the contrary, the pecking order theory suggests a negative relationship between the size of the firm and the debt ratio because information about large firms is expected to be more available, relatively it will reduce information asymmetries level in these large firms. According to that, large firms should borrow less as they have the ability to issue new securities (i.e. new issue of stocks). Thus, the cost of capital for the large firms should be lower than the small firms' cost of capital (Titman and Wessels, 1988; Rajan and Zingales, 1995; Zou and Xiao, 2006).

In line with the trade-off theory view, a number of studies have admitted that firm size is positively related to the use of debt as a financing source (Padron et al., 2005). Whereas, Titman and Wessels (1988), Ooi (1999) and Chen (2003) stated an opposite negative relationship between debt ratios and firm size. Karadeniz et al. (2008) did not find any significant relationship between the size of the Turkish lodging firms over the period 1994-2006 and debt ratios, which is consistent with the findings of Tang and Jang (2007) who also didn't find any significant relationship between the firm's size and its debt ratios for American lodging firms.

\subsection{Non-debt Tax Shields}

The tax shield benefit of financing with debt is not the only method to reduce the firm's tax load (Schulman et al., 1999), Deangelo and Masulis (1980) considered that non-debt tax shields are the alternatives of the tax shields on debt financing, and actually there are several non-debt tax shields, such as accelerated depreciation and investment tax credits (Padron et al., 2005).

Due to that, if a firm uses sufficient tax shields from depreciation to reduce taxable income to zero, debt may not yield additional tax benefit, and capital structure decisions will be based on non-tax considerations (Schulman et al., 1996; Padron et al., 2005).

Therefore, both the pecking order and trade-off theories suggest that there is a negative relationship between non-debt tax shields and debt ratio (DeAngelo and Masulis, 1980; Myers, 1984; Myers and Majluf, 1984).

Sayilgan et al. (2006) and Ozkan (2001) reported a significant negative relationship between non-debts tax shields and debt. Moreover, Upneja and Dalbor (2001) found that non-debt tax shield is negatively related with debt ratio in publicly traded US lodging companies. 


\subsection{Tangibility}

The trade-off theory and the agency cost theory state that tangibility is positively related to debt. Because if a company's tangible assets are high, then these assets can be used as real guarantees to the firm's creditors; therefore, when the value of tangible assets that are used as a guarantee rises, the firm can get more debt easily (Myers and Majluf, 1984; Padron et al., 2005). Moreover, in firms with more intangible assets, the controlling capital expenditures costs are higher; hence, a relatively higher part of the tangible assets is expected to be associated with high leverage (Qian and Wirjanto, 2007; Sangeetha \& Sivathaasan, 2013).

Consistent with the trade off theory and agency theory, many studies indicated a positive relationship between the tangibility and debt ratio such as Zoo and Xiao (2006) and Qian and Wirjanto (2007). In addition to the findings of a number of more recent studies which examined the emerging markets and found a positive relationship between debt ratio and tangibility.

The pecking order theory suggests that firms that own more fixed assets have less asymmetrical information. Therefore, they tend to rely on equity financing and when considering maturity, the pecking order theory suggests that share of fixed assets is positively related to long-term debt financing and negatively related to the short-term debt financing (Sayllgan et al., 2006; Qian and Wirjanto, 2007).

In addition, many studies support the finding of the pecking order theory for example Saylgan et al. (2006) who researched the relationship between the debt ratio and the assets tangibility on 123 Turkish manufacturing firms listed on Istanbul stock exchange for the period between 1993-2002 and found that assets tangibility is negatively related to the long term debt ratio.

\subsection{Growth Opportunities}

Growth opportunities are considered as one of the intangible assets forms and based on that, intangible assets are not those totally collateralizable assets. Thus, firms with significant future growth opportunities are more likely to face financial distresses from debt financing (Ali, 2011). Therefore, the trade off theory and agency theory suggest that firms with great future growth opportunities tend to borrow less than firms with more tangible assets because the intangible assets cannot be collateralized, this prediction suggests a negative relationship between the debt ratio and the growth opportunity (Jensen and Mackling, 1976; Myers, 2001; Sheikh and Wang, 2011). On the other hand, the pecking order theory suggests growth opportunities should be positively related to the debt ratio of a firm (Myers, 1984). Because this theory assumes that there is an asymmetrical information problem between firm managers and outside investors and the firms with higher growth opportunities than the assets they have (particularly small firms) implies a higher demand of debt finance. Therefore, the pecking order theory suggests a positive relationship between growth opportunities and debt level (DeAngelo and Masulis, 1980; Jensen, 1986; Myers, 1984; Myers and Majluf, 1984).

\subsection{Liquidity}

The pecking order and agency cost theories suggest a negative relationship between liquidity and debt ratio, because a firm with a higher liquidity prefers to use internally generated funds (retained earnings or equity) while financing its new investments. Also the agency theory justifies this negative effect by the potential conflict between shareholders and debt holders (Jensen and Meckling, 1976; Myers, 2001; Ramadan, 2009). The trade-off theory suggests a positive relationship between liquidity and debt ratios, because this theory predicts that firms with higher liquidity ratios should borrow more to enhance their ability to meet contractual obligations on time (Rajan and Zingales, 1995). 
Table 1. List of the determinants, theoretical predication signs of their relationships with the debt use and major empirical studies signs

\begin{tabular}{ccc}
\hline Determinants & Theoretical Predication & $\begin{array}{c}\text { Major Empirical Studies } \\
\text { Signs }\end{array}$ \\
\hline Profitability & $\begin{array}{c}\text { Trade off \& agency cost (positive) } \\
\text { Pecking order (negative) } \\
\text { Size }\end{array}$ & Negative \\
& $\begin{array}{c}\text { Trade off \& agency cost (positive) } \\
\text { Pecking order (negative) } \\
\text { Trade off (negative) } \\
\text { Non-debt tax shields }\end{array}$ & Positive \\
& Pecking order (negative) & Negative \\
Tangibility & Trade off \& Agency cost (Positive) & Positive \\
& Pecking order (negative) & \\
Trowth Opportunities & Prade off \& Agency cost (Negative) & Negative \\
& Pecking order (positive) & Trade off (positive) \\
Liquidity & Pecking order \&Agency cost (Negative) & Negative \\
\hline
\end{tabular}

\section{Research Methodology}

\subsection{Data Collection and Sampling}

This study investigates the determinants of capital structure for building and material Egyptian firms listed on the Egyptian Stock Exchange Starting from year 2003 till year 2012; the data used is published, available and collected form kompass, Egypt. The data collected are the financial statements of firms which were used to calculate the profitability ratios including return on assets and return on equity, the growth rates for both sales and assets, total amount of assets, deprecation expenses, share of fixed assets and the amount of both current assets and current liabilities.

The final sample, after considering any missing data, consists of a balanced panel of 18 firms over a period of ten years. Firms under analysis represent the major construction companies in Egypt and it is expected that the sample will succeed in reflecting the leverage image of the country.

\subsection{Variables Development and Measurement}

Building on the research objectives of this study, variables used in this study and their measurements are heavily adopted from the prior literature, this was done in order to facilitate a meaningful comparison of the current study's findings with prior empirical studies in both developed and developing countries. The dependent variable is the debt ratio and long-term debt ratio; the independent variables include profitability, size, non-debt tax shields, tangibility, growth opportunities, and liquidity. Definitions are summarized in Table 2. All variables are measured using book values as the data utilized in this study are extracted from firms' financial statements only.

This study used the debt ratio as a measure of leverage, defined as book value of total debt divided by the book value of total assets. The total debt is the sum of short-term and long-term debt. Moreover, the study used long-term debt ratio as a measure of leverage too, defined as book value of long-term debt divided by the book value of total assets because the strict notion of capital structure refers exclusively to long-term debt. 
Table 2. Variables definition and measurement

\begin{tabular}{|c|c|c|}
\hline Variable & Definition & Measurement \\
\hline \multicolumn{3}{|c|}{ Independent Variables } \\
\hline ROA & Return on assets & (Net income / total assets) \\
\hline ROE & Return on equity & (Net income / owner's equity) \\
\hline SIZE & Firm's size & Natural logarithm of sales \\
\hline TANG & Share of fixed assets & (Net fixed assets /total assets) \\
\hline GROWTH & Growth opportunities & (Annual depreciation expense / total assets) \\
\hline NDTS & Non debt tax shields & $\begin{array}{c}\text { (Net income current year - net income previous } \\
\text { year)/ Net income previous year) }\end{array}$ \\
\hline LIQUIDITY & Current ratio & (Current assets / current liabilities) \\
\hline \multicolumn{3}{|c|}{ Dependent variables } \\
\hline TDR & Total debt ratio & Total Debt / Total Assets \\
\hline LTDR & Long term debt ratio & Long Term Debt / Total Asset \\
\hline
\end{tabular}

\subsection{Research Methods}

This study employed panel data procedures because sample contained data across firms and overtime. Since panel data contained observations on the same cross-sectional units over several time periods, there might be cross-sectional effects on each firm or on a set of group of firms. Several techniques are available to deal with such type of problems, explicitly two panel econometric techniques, namely the fixed and the random effects models, are employed to deal with this problem. The fixed effects model takes into account the individuality of each firm or cross-sectional unit included in the sample by letting the intercept vary for each firm but still assumes that the slope coefficients are constant across firms. The random effects model estimates the coefficients under the assumption that the individual or group effects are uncorrelated with other explanatory variables and can be formulated. Therefore this study employed the Hausman (1978) specification test in order to know if a fixed or random effect model is the best to explain our estimation.

\subsection{Research Hypotheses}

In order to achieve the objectives of this research and based on the literature review, six hypotheses with sub hypotheses have been developed in order to assess the relationship between determinants of capital structure and capital structure decision.

$H_{1}$ : There is either a negative or positive significant relationship between the firm's profitability ratios and the debt level of the firm.

- $\mathrm{H}_{1.1}$ : There is either a negative or positive significant relationship between the firm's ROA and the debt level of the firm.

- $\mathrm{H}_{1.2}$ : There is either a negative or positive significant relationship between the firm's ROE and the debt level of the firm.

$\mathrm{H}_{2}$ : There is either a negative or positive significant relationship between the firm's size ratio and the debt level of the firm.

$H_{3}$ : There is either a negative or positive significant relationship between the firm's tangibility ratio and the debt level of the firm.

$H_{4}$ : There is either a negative or positive significant relationship between the firm's growth rate ratio and the debt level of the firm. 
$H_{5}$ : There is either a negative or positive significant relationship between the firm's non-debt tax shields ratio and the debt level of the firm.

$H_{6}$ : There is either a negative or positive significant relationship between the firm's liquidity ratio and the debt level of the firm.

The study estimates the following equations to represent the models used in order to test the hypotheses:

Model one:

$$
\begin{aligned}
& \mathrm{TDR}_{i t}=\beta_{0}+\beta_{1} \mathrm{ROA}_{\mathrm{it}}+\beta_{2} \mathrm{SIZE}_{\mathrm{it}}+\beta_{3} \mathrm{TANG}_{\mathrm{it}}+\beta_{4} \mathrm{GROW}_{\mathrm{it}}+\beta_{5} \mathrm{NTDS}_{\mathrm{it}}+\beta_{6} \mathrm{LIQ}_{\mathrm{it}}+u_{i t} \\
& \mathrm{LTDR}_{i t}=\beta_{0}+\beta_{1} \mathrm{ROA}_{\mathrm{it}}+\beta_{2} \mathrm{SIZE}_{\mathrm{it}}+\beta_{3} \mathrm{TANG}_{\mathrm{i}}+\beta_{4} \mathrm{GROW}_{\mathrm{it}}+\beta_{5} \mathrm{NTDS}_{\mathrm{it}}+\beta_{6} \mathrm{LIQ}_{\mathrm{it}}+u_{i t}
\end{aligned}
$$

Model two:

$$
\begin{aligned}
\mathrm{LTDR}_{i t} & =\beta_{0}+\beta_{1} \mathrm{ROE}_{\mathrm{it}}+\beta_{2} \mathrm{SIZE}_{\mathrm{it}}+\beta_{3} \mathrm{TANG}_{\mathrm{it}}+\beta_{4} \mathrm{GROW}_{\mathrm{it}}+\beta_{5} \mathrm{NTDS}_{\mathrm{it}}+\beta_{6} \mathrm{LIQ}_{\mathrm{it}}+u_{i t} \\
\mathrm{TDR}_{i t} & =\beta_{0}+\beta_{1} \mathrm{ROE}_{\mathrm{it}}+\beta_{2} \mathrm{SIZE}_{\mathrm{it}}+\beta_{3} \mathrm{TANG}_{\mathrm{it}}+\beta_{4} \mathrm{GROW}_{\mathrm{it}}+\beta_{5} \mathrm{NTDS}_{\mathrm{it}}+\beta_{6} \mathrm{LIQ}_{\mathrm{it}}+{ }_{u i t}
\end{aligned}
$$

Where:

$\mathrm{TDR}_{i t}=$ total debt ratio of firm $\mathrm{i}$ at time $\mathrm{t}$.

$\mathrm{LTDR}_{i t}=$ long-term debt ratio of firm $\mathrm{i}$ at time t.

$\mathrm{ROA}_{\mathrm{it}}=$ profitability of firm $\mathrm{i}$ at time $\mathrm{t}$.

$\mathrm{SIZE}_{\mathrm{it}}=$ size of firm $\mathrm{i}$ at time $\mathrm{t}$.

$\mathrm{TANG}_{\mathrm{it}}=$ tangibility of firm $\mathrm{i}$ at time $\mathrm{t}$.

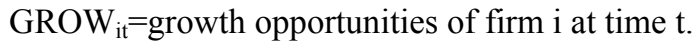

$\mathrm{NTDS}_{\mathrm{it}}=$ non-debt tax shields of firm $\mathrm{i}$ at time t.

$\mathrm{LIQ}_{\mathrm{it}}=$ current ratio of firm $\mathrm{i}$ at time $\mathrm{t}$.

$\mathrm{ROE}_{\mathrm{it}}=$ profitability of firm $\mathrm{i}$ at time $\mathrm{t}$.

$\beta 0=$ common $y$-intercept.

$\beta_{1-} \beta_{6}=$ coefficients of the concerned explanatory variables.

$u_{i t}=$ error term of firm $i$ at time $t$.

\section{Empirical Results and Discussion}

\subsection{Empirical Results}

This section presents the various estimation results and discusses the implications of the empirical findings. The summary of the descriptive statistics of dependent and explanatory variables over the sample period is presented in Table 3, reflecting the capital structures of the analyzed firms. The debt ratio indicates that 90.1 percent of the firms' assets are financed with total debt during the study period, and the long-term debt ratio indicates that 81.6 percent of the firms' assets are financed with long-term debt during the study period.

Table 3. Descriptive statistics of firms for the period 2003-2012

\begin{tabular}{cccccccccc}
\hline & \multicolumn{3}{c}{$\begin{array}{c}\text { Dependent } \\
\end{array}$} & \multicolumn{7}{c}{ Variables } & & \multicolumn{7}{c}{ Independent Variables } \\
\cline { 2 - 8 } & TDR & LTDR & ROA & ROE & SIZE & TANG & GROWTH & NDTS & LIQUIDITY \\
\hline Mean & 0.091 & 0.816 & 0.121 & 0.190 & 8.435 & 0.268 & 24.309 & .025 & 2.88 \\
Max & .562 & .562 & 3.197 & 2.75 & 9.7 & .95 & 1094.87 & .15 & 78.310 \\
Min & 0 & 0 & -.2 & -.74 & 6.14 & 0 & -9.97 & 0 & .133 \\
$\begin{array}{c}\text { Standard } \\
\text { Deviation }\end{array}$ & 0.132 & 0.125 & 0.254 & 0.278 & 0.613 & .232 & 158.370 & 0.021 & 6.617 \\
\hline
\end{tabular}


Prior to estimating the coefficients of the model, the sample data were also tested for multicollinearity. Results are presented in Table 4, which shows that most cross-correlation terms for the explanatory variables are fairly small, thus giving no cause for concern about the problem of multicollinearity among the explanatory variables.

Table 4. Correlation results

\begin{tabular}{|c|c|c|c|c|c|c|c|c|c|c|}
\hline & & \multicolumn{2}{|c|}{$\begin{array}{l}\text { Dependent } \\
\text { Variables }\end{array}$} & \multicolumn{7}{|c|}{ Independent Variables } \\
\hline & & TDR & LTDR & ROA & ROE & SIZE & TANG & GROWH & NDTS & LIQUIDITY \\
\hline \multirow{2}{*}{ TDR } & Correlation & 1 & & & & & & & & \\
\hline & Sig. & & & & & & & & & \\
\hline \multirow{2}{*}{ LTDR } & Correlation & .953 & 1 & & & & & & & \\
\hline & Sig. & .000 & & & & & & & & \\
\hline \multirow{2}{*}{ ROA } & Correlation & $-.188^{*}$ & $-.185^{*}$ & 1 & & & & & & \\
\hline & Sig. & .011 & .012 & & & & & & & \\
\hline \multirow{2}{*}{ ROE } & Correlation & -.078 & -.088 & $.204^{* *}$ & 1 & & & & & \\
\hline & Sig. & .293 & .235 & .006 & & & & & & \\
\hline \multirow{2}{*}{ SIZE } & Correlation & .106 & .112 & .012 & $.253^{* *}$ & 1 & & & & \\
\hline & Sig. & .154 & .133 & .864 & .000 & & & & & \\
\hline \multirow{2}{*}{ TANG } & Correlation & $.223^{* *}$ & $.255^{* *}$ & .104 & .067 & $.121^{*}$ & 1 & & & \\
\hline & Sig. & .002 & .000 & .163 & .368 & .104 & & & & \\
\hline \multirow[t]{2}{*}{ GROW } & Correlation & -.062 & -.053 & .047 & .051 & .094 & $.153^{*}$ & 1 & & \\
\hline & Sig. & .405 & .476 & .528 & .481 & .207 & .039 & & & \\
\hline \multirow[t]{2}{*}{ NDTS } & Correlation & .109 & $.140^{*}$ & .083 & .083 & .094 & $.532^{* *}$ & .117 & 1 & \\
\hline & Sig. & .143 & .059 & .263 & .263 & .206 & .000 & .116 & & \\
\hline \multirow[t]{2}{*}{ LIQUID } & Correlation & .035 & .010 & -.021 & -.043 & .092 & -.139 & -.005 & $-.185^{*}$ & 1 \\
\hline & Sig. & .634 & .884 & .775 & .559 & .218 & .061 & .938 & .012 & \\
\hline
\end{tabular}

Results of these estimation models and the results of the Hausman specification test are reported in Tables 5 and 6. The F-test shows that the null hypothesis is rejected showing that there is a fixed effect and an OLS cannot be used. Moreover, LaGrange Multiplier test shows that a random effect occurs and confirms that an OLS cannot be used. Finally, Hausman Test shows significant results where the null hypothesis is accepted showing that a fixed effect model is preferred with both models LTDR \& TDR with the both ROA and ROE.

Table 5. Regression tests for ROA (Model one)

\begin{tabular}{ccc}
\hline & LTDR & TDR \\
\hline F test & Prob $>\mathrm{F}=0.0000$ & Prob $>\mathrm{F}=0.0000$ \\
LaGrange Multiplier & Prob $>$ Chibar $2=0.0000$ & Prob $>$ Chibar2 $=0.0000$ \\
{$[$ Breusch-Pegan test $]$} & Prob $>$ chi2 $=0.033$ & Prob $>$ chi2 $=0.000$ \\
Hausman Test & & \\
\hline
\end{tabular}


Table 6. Regression tests for ROE (Model two)

\begin{tabular}{ccc}
\hline & LTDR & TDR \\
\hline F test & Prob $>\mathrm{F}=0.0000$ & Prob $>\mathrm{F}=0.0000$ \\
LaGrange Multiplier & Prob $>$ Chibar2 $=0.0000$ & Prob $>$ Chibar $2=0.0000$ \\
$\begin{array}{c}\text { Breusch-Pegan test }] \\
\text { Hausman Test }\end{array}$ & Prob $>$ chi2 $=0.0205$ & Prob $>$ chi $2=0.000$ \\
\hline
\end{tabular}

Therefore, fixed effect regression is used to test the relationship of determinants of capital structure on capital structure decisions. LTDR \& TDR were used as the dependent variables and both ROA and ROE were used as the measures of profitability, SIZE is the natural logarithm of total sales; TANG is the share of fixed assets; GROWTH is the firm's growth rate; NDTS is the non-debt tax shields; and LIQUIDITY is the current ratio, which represent the independent variables. The tests results are shown in Tables 7 and 8.

Table 7. Model one: fixed effect regression using LTDR \& TDR with return on assets (2003-2012)

\begin{tabular}{|c|c|c|c|c|c|}
\hline Variables & & $\begin{array}{c}\text { Model 1.1 } \\
\text { LTDR }_{i t}=\beta_{0} \\
+\beta_{1} \text { ROA }_{\text {it }}+\beta_{2} \text { SI } \\
\text { ZE }_{\text {it }}+\beta_{3} \mathrm{TANG}_{\mathrm{it}} \\
+\beta_{4} \mathrm{GROW}_{\mathrm{it}}+\beta_{5} \\
\mathrm{NTDS}_{\mathrm{it}}+\beta_{6} \mathrm{LIQ}_{\mathrm{it}} \\
+\mathcal{U}_{\mathrm{i}} \\
\text { (Fixed effect) }\end{array}$ & Significance & $\begin{array}{c}\text { Model } 1.2 \\
\mathrm{TDR}_{i t}=\beta_{0} \\
+\beta_{1} \mathrm{ROA}_{\mathrm{it}}+\beta_{2} \mathrm{SI} \\
\mathrm{ZE}_{\mathrm{it}}+\beta_{3} \mathrm{TANG}_{\mathrm{it}} \\
+\beta_{4} \mathrm{GROW}_{\mathrm{it}}+\beta_{5} \\
\mathrm{NTDS}_{\mathrm{it}}+ \\
\beta_{6} \mathrm{LIQ}_{\mathrm{it}}+u_{i t} \\
\text { (Fixed effect) }\end{array}$ & Significance \\
\hline \multirow[b]{2}{*}{ Constant } & Coefficient & 0.266 & \multirow[b]{2}{*}{ Insignificant } & 0.360 & \\
\hline & $\mathrm{P}>|\mathrm{z}|$ & 0.117 & & 0.048 & Insignificant \\
\hline \multirow{2}{*}{ ROA } & Coefficient & -0.527 & \multirow{2}{*}{ Significant } & -.540 & \\
\hline & $\mathrm{P}>|\mathrm{z}|$ & $* * * 0.000$ & & $* * * 0.000$ & Significant \\
\hline \multirow{2}{*}{ SIZE } & Coefficient & -.025 & \multirow{2}{*}{ Insignificant } & -.036 & \\
\hline & $\mathrm{P}>|\mathrm{z}|$ & 0.194 & & .084 & Insignificant \\
\hline \multirow{2}{*}{ TANG } & Coefficient & 0.272 & \multirow{2}{*}{ Significant } & 0.287 & \\
\hline & $\mathrm{P}>|\mathrm{z}|$ & $* * * 0.000$ & & $* * * 0.000$ & Significant \\
\hline \multirow[b]{2}{*}{ GROWTH } & Coefficient & .002 & \multirow[b]{2}{*}{ Insignificant } & .001 & \\
\hline & $\mathrm{P}>|\mathrm{z}|$ & 0.214 & & 0.479 & Insignificant \\
\hline \multirow{2}{*}{ NTDS } & Coefficient & .106 & \multirow{2}{*}{ Insignificant } & .270 & \\
\hline & $\mathrm{P}>|\mathrm{z}|$ & 0.860 & & .676 & Insignificant \\
\hline \multirow{2}{*}{ LIQUIDITY } & Coefficient & .001 & \multirow{2}{*}{ Insignificant } & .002 & \\
\hline & $\mathrm{P}>|\mathrm{z}|$ & 0.824 & & 0.713 & Insignificant \\
\hline \multirow{2}{*}{\multicolumn{2}{|c|}{$\begin{array}{c}\text { \# Of Observations } \\
\text { R square }\end{array}$}} & \multicolumn{2}{|c|}{180} & \multicolumn{2}{|c|}{180} \\
\hline & R square & \multicolumn{2}{|c|}{$33.61 \%$} & \multicolumn{2}{|c|}{$33.27 \%$} \\
\hline
\end{tabular}

Notes:

$* * *$ Significant at 0.01 level

** Significant at 0.05 level

* Significant at 0.1 level 
Table 8. Model two: fixed effect regression using LTDR \& TDR with return on equity (2003-2012)

\begin{tabular}{|c|c|c|c|c|c|}
\hline Variables & & $\begin{array}{c}\text { Model } 2.1 \\
\text { LTDR }_{i t}=\beta_{0} \\
+\beta_{1} \mathrm{ROE}_{\mathrm{it}}+\beta_{2} \mathrm{SIZ} \\
\mathrm{E}_{\mathrm{it}}+\beta_{3} \mathrm{TANG}_{\mathrm{it}}+\beta \\
{ }_{4} \mathrm{GROW}_{\mathrm{it}}+\beta_{5} \mathrm{NT} \\
\mathrm{DS}_{\mathrm{it}}+\beta_{6} \mathrm{LIQ}_{\mathrm{it}}+u_{i} \\
\text { (Fixed effect) }\end{array}$ & Significance & $\begin{array}{c}\text { Model } 2.2 \\
\text { TDR }_{i t}=\beta_{0} \\
+\beta_{1} \mathrm{ROE}_{\mathrm{it}}+\beta_{2} \mathrm{SI} \\
\mathrm{ZE}_{\mathrm{it}}+\beta_{3} \mathrm{TANG}_{\mathrm{it}} \\
+\beta_{4} \mathrm{GROW}_{\mathrm{it}}+\beta_{5} \\
\mathrm{NTDS}_{\mathrm{it}}+ \\
\beta_{6} \mathrm{LIQ}_{\mathrm{it}}+u_{\mathrm{it}} \\
\text { (Fixed effect) }\end{array}$ & Significance \\
\hline \multirow[b]{2}{*}{ Constant } & Coefficient & 0.303 & \multirow[b]{2}{*}{ Insignificant } & 0.400 & \multirow{3}{*}{ Insignificant } \\
\hline & $\mathrm{P}>|\mathrm{z}|$ & 0.088 & & 0.036 & \\
\hline \multirow[b]{2}{*}{ ROE } & Coefficient & -0.205 & \multirow[b]{2}{*}{ Significant } & -.200 & \\
\hline & $\mathrm{P}>|\mathrm{z}|$ & $* * * 0.000$ & & $* * * 0.000$ & Significant \\
\hline SIZE & $\begin{array}{l}\text { Coefficient } \\
\qquad \mathrm{P}>|\mathrm{z}|\end{array}$ & $\begin{array}{l}-.030 \\
0.132\end{array}$ & Insignificant & $\begin{array}{c}-.042 \\
* * .055\end{array}$ & Significant \\
\hline \multirow[b]{2}{*}{ TANG } & Coefficient & 0.284 & \multirow[b]{2}{*}{ Significant } & 0.300 & \\
\hline & $\mathrm{P}>|\mathrm{z}|$ & $* * * 0.000$ & & $* * * 0.000$ & Significant \\
\hline \multirow[b]{2}{*}{ GROWTH } & Coefficient & .004 & \multirow[b]{2}{*}{ Insignificant } & .003 & \\
\hline & $\mathrm{P}>|\mathrm{z}|$ & 0.245 & & 0.228 & Insignificant \\
\hline \multirow[b]{2}{*}{ NTDS } & Coefficient & -.085 & \multirow[b]{2}{*}{ Insignificant } & -.052 & \\
\hline & $\mathrm{P}>|\mathrm{z}|$ & -0.892 & & .938 & Insignificant \\
\hline \multirow[b]{2}{*}{ LIQUIDITY } & Coefficient & -.003 & \multirow[b]{2}{*}{ Insignificant } & -.003 & \\
\hline & $\mathrm{P}>|\mathrm{z}|$ & 0.502 & & 0.615 & Insignificant \\
\hline \multicolumn{2}{|c|}{ \# Of Observations } & \multicolumn{2}{|c|}{180} & \multicolumn{2}{|c|}{180} \\
\hline \multicolumn{2}{|c|}{ R square } & \multicolumn{2}{|c|}{$26.84 \%$} & \multicolumn{2}{|c|}{$26.26 \%$} \\
\hline
\end{tabular}

Notes:

***Significant at 0.01 level

** Significant at 0.05 level

* Significant at 0.1 level

\subsection{Discussion}

With reference to Table 7, the regression model one indicates a strong significant negative relationship between LDTR \& TDR and ROA at level $1 \%$, this result is consistent with the most previous findings such as: Myers and Majluf (1984); Titman \& Weasels (1988) and Sayllgan et al. (2006). While, the firm's size results show a negative but insignificant relationship between size and LTDR \& TDR some prior studies also fail to find any significant relationship between the size and LTDR such as Tang and Jang (2007). Results indicate a strong significant positive relationship between tangibility of firms and LTDR \& TDR at level $1 \%$, which is totally consistent with both the trade off theory and agency theory suggestions. Moreover, a number of prior studies highlighted the same results for example; Rajan and Zingales (1995) and Zou and Xiao (2006). Moreover, a positive but insignificant relationship between growth rate and TDR and LTDR exists. These results are consistent with Deari and media (2007), these 
results support the prediction of the pecking order theory and reject the predictions of the trade off theory and agency cost theory.

Results also show a positive but insignificant relationship between non debt tax shields and LTDR and TDR, the results are inconsistent with the relevant theories of capital structure that suggest negative relation between non debt tax shields and debt level but it is consistent with the positive relationship obtained in the results stated by Graham (2001). Moreover, Brailsford et al. (2002); Karadeniz et al. (2008) and Sheikh and Wang (2011) revealed that non-debt tax shields do not appear to have any significant effect on the debt levels.

Finally, in line with the results highlighted by Sibilkov (2007) and Sangeetha et al. (2013), results found a positive relationship between LTDR and TDR and liquidity. The positive relationship between these variables supports the prediction of trade off theory and rejects the prediction of pecking order and agency cost theories. Moreover, consistent with the result revealed by Hall et al. (2004), found an insignificant relationship between LTDR and TDR and liquidity.

The R-Squared for model one are $33.61 \%$ and $33.27 \%$ respectively, which indicate that the profitability, size, tangibility, non-debt tax shields, growth rate and liquidity explain almost $33 \%$ of the variation in LTDR and of the variation in TDR.

With reference to Table 8, the regression results of model two indicate a negative and strong significant relationship between LTDR and ROE and also between TDR and ROE both at level of 1\%, this result support the pecking order theory assumption and reject the assumption of both trade off and agency cost theories. Moreover, this result is consistent with the results found by Zou and Xiao (2006) and Serrasqueiro and Rogao (2009).

Results indicate insignificant negative relationship between LTDR and the firm's size, while it indicates a significant negative relationship between TDR and firm's size at level 5\%. The negativity of the relationship totally supports the pecking order theory's prediction and rejects predictions of trade off theory and agency cost theory.

These findings are consistent with the results highlighted by Titman and Wessels (1988); Ooi (1999) and Chen (2003). Moreover, the insignificance of the results obtained in model one between both LTDR and firm's size are in line with the results found by Karadeniz et al. (2008) and Tang and Jang (2007).

Results indicate a strong significant positive relationship between tangibility of firms and both LTDR and TDR at level 0.1 , which is totally consistent with both the trade off theory and agency theory suggestions which mean that when the value of the firm's tangible assets that are used as a guarantee rises, the firm can get more debt easily.

Moreover, a number of previous studies examining emerging markets found the same results for example; Rajan and Zingales (1995); Zou and Xiao (2006); and Qian and Wirjanto (2007); Ali (2011) and Sangeetha \& Sivathaasan (2013).

Unlike a number of previous studies that support the prediction of both trade off theory and agency cost theory concerning having a significant negative relationship between firm's growth rate and debt levels such as Zoo and Xiao (2006); Qian and Wirjanto (2007) and Ali (2011). Both LTDR and TDR results revealed an insignificant positive relationship between LTDR and TDR and growth rate. The positivity of the relationship of the results obtained support the pecking order theory that implies a positive relationship between growth opportunities and debt level.

These results are consistent with the results found by Deari and media (2007) who stated that Macedonian firms are positively related to debt ratio. Hall et al. (2004) found that the growth is positively related to long-term debts as well as Dalbor and Upneja (2002) who found that growth is positively related to debt level for restaurant companies.

Moreover, the insignificance of the results obtained in this study between both LTDR and TDR and firm's growth rate are in line with the results found by Karadeniz et al. (2008) and Sheikh and Wang (2011), they revealed that growth rate does not appear to have any significant effect on the capital structure.

An insignificant negative relationship between firm's non-debt taxes shields and both LTDR and TDR, the insignificance of the results obtained in this study between LTDR and TDR and firm's non debt tax shields are in line with the results found by Brailsford et al. (2002) who reveal that non-debt tax shields have no significant relation with any debt level.

Finally, the negative relationship between TDR and LTDR and liquidity support the prediction of pecking order \& agency cost theories and reject the prediction of trade off theory. Also, these results are consistent with the results obtained by Sheikh and Wang (2011) and Šarlija and Harc (2012). 
The R-Squared for the models are $26.84 \%$ and $26.26 \%$ respectively, which indicate that profitability, size, tangibility, non-debt tax shields, growth rate and liquidity explain almost $26 \%$ of the variation in LTDR and of the variation in TDR.

\section{Conclusion}

The main objective of the study is to determine the capital structure of building material and construction companies in Egypt. Since the building material and construction sector acquires the largest share of the capital of the economy. Therefore, the decision to finance these companies with internal or external source is very crucial.

The sample of this study includes 18 building material and construction Egyptian firms listed in the Egyptian stock exchange. The methodology employed in this study is panel data analysis over a ten years period from 2003 to 2012 . Data was collected from the firm's annual reports.

The results reveal a significant negative relationship between debt level and firm's profitability and firm's size. A positive and significant relationship has been confirmed between debt level and firm's tangibility, the rationale behind this situation is that when the company has more tangible assets the demand for debt in financing the assets also increases.

Debt level has a positive but insignificant relationship with firm's growth opportunity; non-debt tax shields and liquidity in model one of the analyses, where ROA used as the measurement of the profitability. On the other hand, debt level has a negative and insignificant relation with firm's non-debt tax shields and firm's liquidity in model two of the analyses where ROE used as the measurement of the profitability.

These findings conclude that firm's profitability, size and tangibility play a major role in the determination of the financial leverage in Egyptian building material and construction firms while growth opportunity, non-debt tax shields and liquidity have a weak role.

This study has important implications for the academic and practitioners. As on an academic level, the study fills the gap in the existing literature regarding capital structure in emerging markets. Researchers can utilize the results and methodology followed in this study for their further research and also they can incorporate some other important factors (i.e. managerial behavior, political instability, credit rating, potential costs of financial distress, financial flexibility, amongst other factors.) and this could be done for a longer period and across more industries so the results could be generalized to most of the Egyptian companies. On the other hand, the study benefits the financial managers as well as the researchers. The financial managers should consider these determinants as guidelines or indicators before taking the financing -leverage- decisions in order to choose the most favorable capital structure for the company so that it maximizes the shareholders' value.

\section{Research Limitations}

Egypt is a developing country where the electronic databases are unavailable. This leads to certain limitations in the data availability.

The research is applied on a specific sector, namely; building material and construction, and hence the findings only apply for this certain sector and cannot be generalized to the rest of sectors existing in the Egyptian economy.

Moreover, the structure of the financial statements was not in the same format, even though, the same elements existed which made it difficult to extract the same level of information required for the purpose of this research.

Finally, since the research is covering the period from 2003 until 2012. The findings of 2008- the year of the global financial crisis- might be misleading because of the impact of this financial crisis that might have had on firms, and hence affected their financial statements.

\section{Recommendations for Future Research}

According to the study objectives the study can recommend future studies which spotlight the following areas:

First, the factors affecting the capital structure have been found to vary across different countries, industries, and firms. Empirical studies have generally investigated the extent to which the trade-off and pecking order theories explain companies' capital structures. Thus, other capital structure theories should also be tested empirically. Future studies may also compare capital structure of construction companies in various countries.

Second, this study covered only the determinants of total debt and long-term debt to total assets of sample constriction firms. Future researches may investigate the determinants of short-term debt to assets. 
Third, this study used profitability, size, tangibility, growth opportunity, non-debt tax shields and liquidity as the determinants of capital structure. Future studies can use other.

\section{Acknowledgements}

First of all we would like to thank all the people who supported us during different phases of this research, as well as all people who helped us to make the required data available and participating in our research. Without your help this research would not have been possible.

\section{References}

Ali, L. (2011). The Determinants of Leverage of the Listed-Textile Companies in India. European Journal of Business and Management, 3(12), 54-59.

Brailsford, T. J., Oliver, B. R., \& Pua, S. L. H. (2002). On the relation between ownership structure and capital structure. Journal of Accounting \& Finance, 42(1), 1-26. http://dx.doi.org/10.1111/1467-629X.00001

Chen, J. J. (2003). Determinants of capital structure of Chinese-listed companies. Journal of Business Research, 57, 1341-51. http://dx.doi.org/10.1016/S0148-2963(03)00070-5

Dalbor, M., \& Upneja, A. (2002). Factors affecting the long-term debt decision of restaurant firms. Journal of Hospitality \& Tourism Research, 26(4), 422-32. http://dx.doi.org/10.1177/109634802237487

DeAngelo, H., \& Masulis, R. W. (1980). Optimal capital structure under corporate and personal taxation. Journal of Financial Economics, 8, 3-29. http://dx.doi.org/10.1016/0304-405X(80)90019-7

Deari, F., \& Media, D. (2007). The Determinants of Capital Structure: Evidence from Macedonian listed and unlisted Companies. Working Paper, Analete Scientific University, Republic of Macedonia.

Fattouh, B., Scaramozzino, P., \& Harris, L. (2005). Capital structure in South Korea: a quantile regression approach. Journal of Development Economics, 76(1), 231- 250. http://dx.doi.org/10.1016/j.jdeveco.2003.12.014

Graham, J. (2001). Analysis of the Financial Management Techniques currently employed by large U.S. Corporations. Journal of business Finance and Accounting, 10, 623-645.

Hausman, J. (1978). Specification tests in econometrics. Econometrica, 46(6), 1251-1271. http://dx.doi.org/10.2307/1913827

Jensen, M., \& Meckling, W. (1976). Theory of the Firm: Managerial Behavior, Agency Costs, and Capital Structure. Journal of Financial Economics, 3(4), 305-360. http://dx.doi.org/10.1016/0304-405X(76)90026-X

Karadeniz, E., Kandir, S. Y., Balcilar, M., \& Onal, Y. B. (2009). Determinants of capital structure: evidence from Turkish lodging companies. International Journal of Contemporary Hospitality Management, 21(5), 594-609. http://dx.doi.org/10.1108/09596110910967827

Kompass Egypt. (2013). Company database, features all Egyptian large and medium companies 143 Eltharir St., Dokki, Giza.

Modigliani, F., \& Miller, M. H. (1958). The cost of capital, corporation finance, and the theory of investment. American Economic Review, 48(3), 261-296.

Modigliani, F., \& Miller, M. H. (1963). Corporate income taxes and cost of capital: a correction. American Economic Review, 53, 443-53.

Myers, S. C. (1984). The capital structure puzzle. The Journal of Finance, 39(3), 575-92. http://dx.doi.org/10.2307/2327916

Myers, S. C. (2001). Capital structure. The Journal of Economic Perspectives, 15(2), 81-102. http://dx.doi.org/10.1257/jep.15.2.81

Myers, S. C., \& Majluf, N. S. (1984). Corporate financing and investment decisions when firms have information that investors do not have. Journal of Financial Economics, 13(2), 187-221. http://dx.doi.org/10.1016/0304-405X(84)90023-0

Nadeem Ahmed Sheikh, \& Wang, Z. (2011). Determinants of capital structure: An empirical study of firms in manufacturing industry of Pakistan. Managerial Finance, 37(2), 117-133. http://dx.doi.org/10.1108/03074351111103668

Ooi, J. (1999). The determinants of capital structure: evidence on UK property companies. Journal of Property Investment \& Finance, 17(5), 312-315. http://dx.doi.org/10.1108/14635789910294886 
Ozkan, A. (2001). Determinants of Capital Structure and Adjustment to Long Run Target: Evidence from UK Company Panel Data. Journal of Business Finance \& Accounting, 28(1/2), 175-198.

Padron, Y. G., Apolinario, R. M. C., Santana, O. M., Conception, M., Martel, V., \& Sales, L. J. (2005). Determinant factors of leverage: an empirical analysis of Spanish corporations. Journal of Risk Finance, 6(1), 60-68. http://dx.doi.org/10.1108/15265940510581279

Qian, Y., Tian, Y., \& Wirjanto, T. S. (2007). An Empirical Investigation into the Capital-Structure Determinants of Publicly Listed Chinese Companies: A Static Analysis. Retrieved from www.arts.uwaterloo.ca/twirjant

Ramadan, A. H. (2009). Determinants of Capital structure and the Firm's financial performance: An Application on the UK Capital market. Ph.D thesis, University of Surrey, Guildford, UK.

Ross, S. A. (1977). The determination of financial structure: the incentive signaling approach. Bell Journal of Economics, 8(1), 23-40. http://dx.doi.org/10.2307/3003485

Sangeetha, M., \& Sivathaasan, N. (2013). Factors Determining Capital Structure: A Case study of listed companies in Sri Lanka. Journal of Finance and Accounting, 4(6), 236-247.

Šarlija, N., \& Harc, M. (2012). The impact of liquidity on the capital structure: a case study of Croatian firms. Business Systems Research, 3(1), 30-36. http://dx.doi.org/10.2478/v10305-012-0005-1

Sayllgan, G., Karabacak, H., \& Kucukkocaoglu, G. (2006). The Firm-Specific Determinants of Corporate Capital Structure: Evidence from Turkish Panel Data. Retrieved from www.baskent.edu.tr/gurayk/kisiselcapstrpaper.pdf

Schulman, C. T., Deborah, W. T., Sellers, K. F., \& Kennedy, D. B. (1996). Effects of tax integration and capital gains tax on corporate leverage. National Tax Journal, 49(1), 31-54.

Serrasqueiro, Z. M. S., \& Rogã o, M. C. R. (2009). Capital structure of listed Portuguese companies: determinants of debt adjustment. Review of Accounting and Finance, 8(1), 54-75. http://dx.doi.org/10.1108/14757700910934238

Sibilkov, V. (2007). Asset Liquidity and Capital Structure, Sheldon B. Lubar School of Business. University of Wisconsin -Milwaukee, Electronic copy. Retrieved from https://pantherfile.uwm.edu/sibilkov/www/liquidity.pdf

Tang, C. H., \& Jang, S. S. (2007). Revisit to the determinants of capital structure: a comparison between lodging firms and software firms. International Journal of Hospitality Management, 26(1), 175-87. http://dx.doi.org/10.1016/j.ijhm.2005.08.002

Titman, S., \& Wessels, R. (1988). The determinants of capital structure choice. The Journal of Finance, 43(1), 1-19. http://dx.doi.org/10.1111/j.1540-6261.1988.tb02585.x

Upneja, A., \& Dalbor, M. (2001). The choice of long-term debt in the US lodging industry. UNVL Journal of Hospitality, Tourism and Leisure Science. Retrieved from http://hotel.unlv. edu/res_journalPubsArticle.html

Zou, H., \& Xiao, J. Z. (2006). The financing behavior of listed Chinese firms. The British Accounting Review, 38(1), 239. 